\section{Modeling human-caused forest fire ignition for assessing forest fire danger in Austria}

\author{
Natalie Arndt ${ }^{(1)}$, Harald Vacik ${ }^{(1)}$, Valerie Koch ${ }^{(2)}$, Alexander Arpaci ${ }^{(1)}$, \\ Hartnut Gossow ${ }^{(3)}$
}

Forest fires have not been considered as a significant threat for mountain forests of the European Alpine Space so far. Climate change and its effects on nature, ecology, forest stand structure and composition, global changes according to demands of society and general trends in the provision of ecosystem services are potentially going to have a significant effect on fire ignition in the future. This makes the prediction of forest fire ignition essential for forest managers in order to establish an effective fire prevention system and to allocate fire fighting resources effectively, especially in alpine landscapes. This paper presents a modeling approach for predicting human-caused forest fire ignition by a range of socio-economic factors associated with an increasing forest fire danger in Austria. The relationship between touristic activities, infrastructure, agriculture and forestry and the spatial occurrence of forest fires have been studied over a 17-year period between 1993 and 2009 by means of logistic regression. Some 59 independent socio-economic variables have been analyzed with different models and validated with heterogeneous subsets of forest fire records. The variables included in the final model indicate that railroad, forest road and hiking trail density together with agricultural and forestry developments may contribute significantly to fire danger. The final model explains $60.5 \%$ of the causes of the fire events in the validation set and allows a solid prediction. Maps showing the fire danger classification allow identifying the most vulnerable forest areas in Austria and are used to predict the fire danger classes on municipality level.

Keywords: Forest Fire, European Alpine Space, Austria, Infrastructure, Socio-economic Factors, Geographic Information System, Logistic Regression

\section{Introduction}

Fire danger is generally understood as the likelihood of a fire to occur (Chuvieco \& Congalton 1989, Chuvieco et al. 2009). In fire danger assessments the evaluation of the chances of fire ignition is generally done by identifying the contributing factors and their integration into an index quantifying the level of danger (Chuvieco et al. 2003, Sebastián-López et al. 2008, Chuvieco et al. 2009, Conedera et al. 2011). For the proba- bility of a fire to occur, two agents are identified: natural (predominantly lightning) and anthropogenic causes, which are mainly related to human activities. In this context, the the result of the direct or indirect presence of human activity in the landscape (Martinez et al. 2009). International studies indicate that roughly $90 \%$ of forest fires are human-caused, whereas only a small percentage of forest fires have natural causes, i.e., lightning probability of human-caused fire ignition is

(1) Department of Forest and Soil Sciences, Institute of Silviculture, University of Natural Resources and Life Sciences, Peter Jordan Str. 82, A-1190 Vienna (Austria); (2) Department of Landscape, Spatial and Infrastructure Sciences, Institute of Surveying, Remote Sensing and Land Information, University of Natural Resources and Life Sciences, Peter Jordan Str. 82, A-1190 Vienna (Austria); (3) Department of Integrative Biology and Biodiversity Research, Institute of Wildlife Biology and Game Management, University of Natural Resources and Life Sciences, Peter Jordan Str. 82, A-1190 Vienna (Austria)

@ Natalie Arndt (natalie_arndt@yahoo.com)

Received: Dec 18, 2012 - Accepted: Apr 14, 2013

Citation: Arndt N, Vacik H, Koch V, Arpaci A, Gossow H, 2013. Modelling human-caused forest fire ignition for assessing forest fire danger in Austria. iForest 6: 315-325 [online 2013-07-16] URL: http://www.sisef.it/iforest/contents/?id=ifor0936-006

Communicated by: Marco Borghetti

(Cardille et al. 2001, Grissino-Mayer et al. 2004, Mollicone et al. 2006, Vacik et al. 2011). In Europe, human activities account for the majority of fire ignition (Leone et al. 2002, Catry et al. 2009, Martinez et al. 2009).

Various goods and services provided by forests such as water supply, carbon sinks, recreation and protection services are most likely to be impacted by wildfires (Wotton et al. 2003, Grissino-Mayer et al. 2004, Brown et al. 2004, Fried et al. 2004, Catry et al. 2009, Dumas et al. 2008, Weibel et al. 2009). Especially in the densely populated European mountain forests the danger of fire ignition is of high significance for the maintenance of its ecosystem goods and services as these ecosystems are very sensitive to environmental changes (Steininger \& WeckHannemann 2002, Lindner et al. 2010). Additionally the economic value of goods and services of the alpine region experiences an increased recognition especially through sporting activities and outdoor recreation (Hall \& Page 2009). Furthermore, the alpine region is crossed by important transit and trade routes. They aid in promoting tourism in the mountainous regions across Europe (Gambino \& Romano 2003, Nordregio 2004, Brauchle 2006), which is leading to an increased development of touristic infrastructure besides the extensive use by naturebased tourism (Gambino \& Romano 2003, Heinrichs et al. 2010). The herewith associated rise in pressure on forests through a growing number of tourists is potentially increasing danger of fire ignition. The increasing significance of transportation for the supply of living goods as well as for the provision of access to services potentially affects fire ignition as well. Several international studies have shown the significance of the distance of forest fires to roads, settlements and infrastructure, or specific land uses or even its abandonment as predisposition for fire ignition (Vega-Garcia et al. 1995, Goldammer 2003, Kalabokidis et al. 2002, Catry et al. 2009, Martinez et al. 2009).

Although human factors are relatively important when analyzing forest fire ignition, little attention has been paid to their significance so far. The reason is the relatively high complexity of human behavior, which is often hard to measure. Especially data on human activities in forest areas are often lacking (Martell et al. 1987, Vega-Garcia et al. 1995). Due to the difficulties in obtaining detailed data on human activities, the human factor for wildfire ignition is difficult to model, since behavioral factors need to be identified, quantified and mapped (see Vasilakos et al. 2007, Martinez et al. 2009). In the past, estimations of human activities have been based on indirect assessments. 
Underlying data for studies on the influence of socio-economic variables on forest fire ignition have been derived from census data or surveys (Donoghue \& Main 1985, Martinez et al. 2009). However, the influence of human factors on forest fire danger is closely linked to the characteristics of the region. A number of studies analyzing the influence of human factors on forest fires have been conducted and decision support systems have been established in southern Europe (Kalabokidis et al. 2002, Goldammer 2003, Sebastián-López et al. 2008, Martinez et al 2009). However, a detailed analysis of the role of human factors on forest fire danger in the European Alps is rather rudimentary and has primarily been conducted together with the analysis of the influence of climate change on forest fire occurrence (Weibel et al. 2009, Wastl et al. 2012) or the selective burning of forest vegetation (Pezzati et al. 2009).

Austria is a predominantly Alpine country with a highly diverse landscape ranging from the plains in the east to the Alps in the west and a forest cover of $47.2 \%$. As the country is a popular tourist destination and is crossed by important transit routes, the influence of human factors on fire ignition probability cannot be disregarded. Compared to current research in other - especially southern European countries - forest fires have not been a serious concern in Austria so far. Forest fire records, which have been collected for Austria, indicate that the majority of forest fires are human-caused, whereas lightning accounts for $15 \%$ of the forest fires (Müller et al. 2013). Considering the vulnerability of the whole Alpine Region to climate change and land abandonment (Beniston et al. 1997, Theurillat \& Guisan 2001, Schumacher \& Bugmann 2006, Gehrig-Fasel et al. 2007, Wastl et al. 2012) we regard the investigation of the human-caused fire ignition as substantial for a better understanding of fire danger for Austrian forests and the goods and services they provide.

The objective of this study is to present a fire danger model to predict the spatial occurrence of human-caused fire ignitions in Austria. Records of human-caused forest fires for the period from 1993 to 2009 have been extracted from the AFFRI wildfire database and have been used together with potentially explanatory socio-economic variables in order to develop different logistic regression models and describe the influence of socio-economic factors on forest fire ignition. A model has been chosen, which represents the influence of the socio-economic factors on forest fire ignition probability the best. Based on the validation of the model's performance, maps of potential fire ignition in Austria related to socio-economic factors have been produced.

\section{Material and methods}

\section{Study area and fire database}

Austria is a central European country covering $83855 \mathrm{~km}^{2}$ and a population size of 8.47 million people. Austria is a largely alpine country $(68 \%)$ with a temperate to alpine climate. Average temperatures range from $-10{ }^{\circ} \mathrm{C}$ in winter to $20^{\circ} \mathrm{C}$ in summer. Austria has a total number of 2357 municipalities with areas ranging from $32.4 \mathrm{~km}^{2}$ for the smallest municipality to $466.9 \mathrm{~km}^{2}$ for the largest municipality. Some $47.6 \%$ of Austria is covered with forests, out of which the main part is coniferous forest (AFI 2011).

Underlying data on forest fires have been obtained from the wildfire database, which has been created within the frame of the Austrian Forest Fire Research Initiative (AFFRI) currently taking place at the University of Natural Resources and Life Sciences, Vienna. Wildfire records have been obtained from municipalities, fire brigades, the OEBB (Austrian Railway Company) as well as the Federal Ministry of Agriculture and Forestry, Environment and Water Management (BMLFUW). The database includes information for each fire record on geographical coordinates and other characteristics (e.g., municipality, cause of fire, time of day of start and end of fire, time of detection, ignition type, vegetation type and tree species affected) for the period 1993-2009 (Vacik et al. 2011, Eastaugh \& Vacik 2012). Given that this study analyzes the role of socio-economic factors for forest fire ignition, only 955 human-caused forest fires recorded in the database and matching the selected criteria (e.g., full record of information available, size of the burned area) have been used for this study, totaling to 1660 fire records. Lightning caused fires have been analyzed in a separate study and are not part of this dataset (Müller et al. 2013). Fires in agricultural areas have not been considered.

\section{Parameter and model selection}

Different methods ranging from logistic regression to artificial neural networks to classification and regression tree algorithms have been used to model wildfire occurrence. Logistic regression is one of the most frequently used methods (Andrews et al. 2003, Vasconcelos et al. 2001, Chuvieco et al. 2003, Amatulli et al. 2007, Brosofske et al. 2007, Zhang et al. 2010). It has been used to develop regional models with a large spatial extent (Chuvieco et al. 1999, Martinez et al. 2009) as well as for developing models on a local scale (Vega-Garcia et al. 1995, Vasconcelos et al. 2001). In other studies logistic regression has been used to develop temporal models that are used to predict daily human-caused fire occurrence (Martell et al. 1987, Loftsgaarden \& Andrews 1992, Vega-Garcia et al. 1995).
Model events with binary or dichotomous variables - such as the presence or absence of fire ignition - are best described by means of logistic regression. Forward stepwise logistic regression has been chosen for this study, since the interest was on identifying the significance of a group of predicting variables affecting fire occurrence as well as to model ignition probability. Moreover, logistic regression proved to be relatively flexible, since it accepts a combination of continuous, categorical and non-normally distributed variables (Bellgardt 1997).

In relation to the human-caused forest fires recorded in our database, five different sets of 955 points randomly distributed over Austria have been generated with ArcGISTM and were classified as "no fire events". These randomly generated sets of points have been joined with the 955 human-caused "fire events" from the forest fire dataset in order to be able to quantify the predictive ability of the socio-economic variables chosen. Ignition and non-ignition points were coded in a binary format (0: no fire; 1 : fire) representing the dependent variable fire ignition. In order to be able to test the final model, 100 fire ignition points and 100 no-fire ignition points were selected randomly from each of the five datasets for validation, resulting in five sets with 855 fire and 855 no-fire events for calculating the model.

The analysis is based on the following function (eqn. 1):

$$
P(z)=\frac{1}{\left(1+e^{-z}\right)}
$$

where $P$ is the probability of occurrence of an event and $z$ is the linear function of the independent variables (eqn. 2):

$$
z=b_{0}+b_{1} x_{1}+b_{2} x_{2}+\ldots+b_{n} x
$$

The presence or absence of forest fire ignitions has been chosen as the dependent variable for the analysis.

Previous studies have identified a number of human factors to be significant for wildfire ignition (Tab. 1 - Cardille et al. 2001, Leone et al. 2003, Chuvieco et al. 2003, Vega-Garcia et al. 1995, Brosofske et al. 2007, Amatulli et al. 2007, Vilar et al. 2010). Based on the background of these studies, some 59 socio-economic parameters that were assumed to be characteristic for Austrian conditions were chosen as independent variables to model the potential influence on the fire danger. These socio-economic variables were clustered in five groups with similar characteristics on municipal level:

- Factors related to the human presence in urban, agricultural and forested areas in general (e.g., number of inhabitants, size of urban area);

- Factors related to touristic infrastructures and their activities (e.g., number of over- 
night stays, number of huts, cable cars and hiking trails);

- Factors related to agricultural production (e.g., agricultural area, intensity of agricultural operations);

- Factors related to forest management (e.g., density of forest area, forest roads, forestry operations, storm blow-down salvage harvesting);

- Factors related to infrastructure and their density (e.g., roads, railroads).

Tab. 1 shows all independent socio-economic variables chosen for the study.

Information on socio-economic factors in this study has been derived from the Statistik Austria census database on municipality level as well as from the Corine Landcover classification (Environmental Agency Austria 2012). Besides the above socio-economic data, additional variables have been ge- nerated in order to obtain socio-economic factors potentially relevant for forest fire ignition.

The logistic regression analysis was performed using SPSS ${ }^{\circledR}$ software, version 15.0.

\section{Model construction}

In order to eliminate multicollinearity between the variables selected for this study, the Pearson correlation analysis has been

Tab. 1 - Potential human factors influencing forest fire ignition.

\begin{tabular}{|c|c|c|c|c|}
\hline Modules & Abbreviation & Built-in module & Measure & Data source \\
\hline- & TOTAREA & Total area of municipality & $\mathrm{km}^{2}$ & Corine land cover \\
\hline \multirow{6}{*}{$\begin{array}{l}\text { Urban } \\
\text { module }\end{array}$} & INHAB & Inhabitants of municipality & Numerical & Statistik Austria \\
\hline & RESAREA & Residential area & $\mathrm{km}^{2}$ & Corine land cover \\
\hline & INHAB/TOTAREA & Inhabitants / total area & $\mathrm{N} / \mathrm{km}^{2}$ & - \\
\hline & INHAB/RESAREA & Inhabitants / residential area & $\mathrm{N} / \mathrm{km}^{2}$ & - \\
\hline & INHAB/AGRAREA & Inhabitants / agricultural area & $\mathrm{N} / \mathrm{km}^{2}$ & - \\
\hline & INHAB/FORAREA & Inhabitants / forest area & $\mathrm{N} / \mathrm{km}^{2}$ & - \\
\hline \multirow{15}{*}{$\begin{array}{l}\text { Touristic } \\
\text { module }\end{array}$} & OVERN/INHAB & Overnights / inhabitants & Numerical & - \\
\hline & CABLE & Cable cars & Numerical & http://www.seilbahnen.at \\
\hline & HUT & Huts & Numerical & http://www.huetten.at \\
\hline & HIKETRAIL & Hiking trails & $\mathrm{km}$ & Corine land cover \\
\hline & CABLE/TOTAREA & Cable cars / total municipal area & $\mathrm{N} / \mathrm{km}^{2}$ & - \\
\hline & CABLE/RESAREA & Cable cars / residential area & $\mathrm{N} / \mathrm{km}^{2}$ & - \\
\hline & CABLE/AGRAREA & Cable cars / agricultural area & $\mathrm{N} / \mathrm{km}^{2}$ & - \\
\hline & CABLE/FORAREA & Cable cars / forest area & $\mathrm{N} / \mathrm{km}^{2}$ & - \\
\hline & HUT/RESAREA & Huts / residential area & $\mathrm{N} / \mathrm{km}^{2}$ & - \\
\hline & HUT/AGRAREA & Huts / agricultural area & $\mathrm{N} / \mathrm{km}^{2}$ & - \\
\hline & HUT/FORAREA & Huts / forested area & $\mathrm{N} / \mathrm{km}^{2}$ & - \\
\hline & HIKETRAIL/TOTAREA & Hiking trails / total municipal area & $\mathrm{km} / \mathrm{km}^{2}$ & - \\
\hline & HIKETRAIL/RESAREA & Hiking trails / residential area & $\mathrm{km} / \mathrm{km}^{2}$ & - \\
\hline & HIKETRAIL/AGRAREA & Hiking trails / agricultural area & $\mathrm{km} / \mathrm{km}^{2}$ & - \\
\hline & HIKETRAIL/FORAREA & Hiking trails / forested area & $\mathrm{km} / \mathrm{km}^{2}$ & - \\
\hline \multirow{10}{*}{$\begin{array}{l}\text { Agricultural } \\
\text { module }\end{array}$} & AGRAREA & Agricultural area & $\mathrm{km}^{2}$ & Corine land cover \\
\hline & AGRAREA/TOTAREA & Agricultural area / total municipal area & $\mathrm{km}^{2} / \mathrm{km}^{2}$ & - \\
\hline & AGROP & Agricultural operations & Numerical & Statistik Austria \\
\hline & AGRPAST & Agricultural holding with pasture land & Numerical & Statistik Austria \\
\hline & AGR/TOTAREA & Agricultural operations / total municipal area & $\mathrm{N} / \mathrm{km}^{2}$ & - \\
\hline & AGR/RESAREA & Agricultural operations / residential area & $\mathrm{N} / \mathrm{km}^{2}$ & - \\
\hline & AGR/AGRAREA & Agricultural operations / agricultural area & $\mathrm{N} / \mathrm{km}^{2}$ & - \\
\hline & AGR/FORAREA & Agricultural operations / forest area & $\mathrm{N} / \mathrm{km}^{2}$ & - \\
\hline & AGRPAST/TOTAREA & Agricultural holding with pasture land / total municipal area & $\mathrm{N} / \mathrm{km}^{2}$ & - \\
\hline & AGRPAST/REAREA & Agricultural holding with pasture land / residential area & $\mathrm{N} / \mathrm{km}^{2}$ & - \\
\hline \multirow{12}{*}{$\begin{array}{l}\text { Forest } \\
\text { module }\end{array}$} & FORAREA & Forest area & - & - \\
\hline & FORAREA/TOTAREA & Forest area / total municipal area & $\mathrm{km}^{2}$ & Corine land cover \\
\hline & FORROAD & Forest roads & $\mathrm{km}$ & Corine land cover \\
\hline & FORHOL & Forestry operations & Numerical & Statistik Austria \\
\hline & FORROAD/TOTAREA & Forest roads / total municipal area & $\mathrm{km} / \mathrm{km}^{2}$ & - \\
\hline & FORROAD/RESAREA & Forest roads / residential area & $\mathrm{km} / \mathrm{km}^{2}$ & - \\
\hline & FORROAD/AGRAREA & Forest roads / agricultural area & $\mathrm{km} / \mathrm{km}^{2}$ & - \\
\hline & FORROAD/FORAREA & Forest roads / forest area & $\mathrm{km} / \mathrm{km}^{2}$ & - \\
\hline & FORHOL/TOTAREA & Forestry operations / total area of municipality & $\mathrm{N} / \mathrm{km}^{2}$ & - \\
\hline & FORHOLRESAREA & Forestry operations / residential area & $\mathrm{N} / \mathrm{km}^{2}$ & - \\
\hline & FORHOL/AGRAREA & Forestry operations / agricultural area & $\mathrm{N} / \mathrm{km}^{2}$ & - \\
\hline & FORHOL/FORAREA & Forestry operations / forest area & $\mathrm{N} / \mathrm{km}^{2}$ & - \\
\hline \multirow{10}{*}{$\begin{array}{l}\text { Infrastructural } \\
\text { module }\end{array}$} & ROAD & Roads & $\mathrm{km}$ & Corine land cover \\
\hline & RAIL & Railroads & $\mathrm{km}$ & Corine land cover \\
\hline & ROAD/TOTAREA & Roads / total municipal area & $\mathrm{km} / \mathrm{km}^{2}$ & - \\
\hline & ROAD/RESAREA & Roads / residential area & $\mathrm{km} / \mathrm{km}^{2}$ & - \\
\hline & ROAD/AGRAREA & Roads / agricultural area & $\mathrm{km} / \mathrm{km}^{2}$ & - \\
\hline & ROAD/FORAREA & Roads / forest area & $\mathrm{km} / \mathrm{km}^{2}$ & - \\
\hline & RAIL/TOTAREA & Railroads / total municipal area & $\mathrm{km} / \mathrm{km}^{2}$ & - \\
\hline & RAIL/RESAREA & Railroads / residential area & $\mathrm{km} / \mathrm{km}^{2}$ & - \\
\hline & RAIL/AGRAREA & Railroads / agricultural area & $\mathrm{km} / \mathrm{km}^{2}$ & - \\
\hline & RAIL/FORAREA & Railroads / forest area & $\mathrm{km} / \mathrm{km}^{2}$ & - \\
\hline
\end{tabular}


Tab. 2 - Model outcomes for choice of best model fit. (df): degrees of freedom.

\begin{tabular}{llccccc}
\hline $\begin{array}{l}\text { Omnibus Test } \\
\text { of Model } \\
\text { coefficients }\end{array}$ & Parameters & Model 1 & Model 2 & Model 3 & Model 4 & Model 5 \\
\hline Step & $\chi^{2}$ & 9.471 & 79.014 & 71.923 & 91.032 & 106.471 \\
& df & 1 & 1 & 1 & 1 & 1 \\
& Prob & 0.002 & 0.000 & 0.000 & 0.000 & 0.000 \\
\hline Block & $\chi^{2}$ & 69.784 & 79.014 & 71.923 & 91.032 & 106.471 \\
& $\mathrm{df}$ & 2 & 1 & 1 & 1 & 1 \\
& Prob & 0.000 & 0.000 & 0.000 & 0.000 & 0.000 \\
\hline Model & $\chi^{2}$ & 190.558 & 208.863 & 264.397 & 238.587 & 210.025 \\
& $\mathrm{df}$ & 5 & 6 & 5 & 4 & 4 \\
& Prob & 0.000 & 0.000 & 0.000 & 0.000 & 0.000 \\
\hline Model Summary & -2 Log-Likelihood & 2177.233 & 2158.925 & 2102.002 & 2131.976 & 2160.539 \\
& Cox \& Snell $\mathrm{R}^{2}$ & 0.106 & 0.115 & 0.143 & 0.130 & 0.116 \\
& Nagelkerke's $\mathrm{R}^{2}$ & 0.141 & 0.153 & 0.191 & 0.174 & 0.154 \\
\hline Hosmer- & $\chi^{2}$ & 16.365 & 21.009 & 16.541 & 8.243 & 22.069 \\
Lemeshow-Test & $\mathrm{df}$ & 8 & 8 & 8 & 8 & 8 \\
& Prob & 0.037 & 0.007 & 0.035 & 0.410 & 0.005 \\
\hline
\end{tabular}

Tab. 3 - Variables included in the five models.

\begin{tabular}{ccccc}
\hline Model 1 & Model 2 & Model 3 & Model 4 & Model 5 \\
\hline HIKETRAIL/ & HIKETRAIL/ & HIKETRAIL/ & HIKETRAIL/ & HIKETRAIL/ \\
TOTAREA & TOTAREA & TOTAREA & TOTAREA & TOTAREA \\
- & - & HIKETRAIL/ & - & HIKETRAIL/ \\
& & FOR & & FOR \\
- & AGRPAST & - & - & - \\
AGR/TOTAREA & - & - & - & - \\
- & FORHOL & - & FORHOL & - \\
- & - & FORHOL/ & - & - \\
FORROAD/ & FORROAD/ & FORROAD/ & FORROAD/ & FORROAD/ \\
TOTAREA & TOTAREA & TOTAREA & TOTAREA & TOTAREA \\
ROAD/ & - & - & - & - \\
TOTAREA & & & & \\
RAIL/TOTAREA RAIL/TOTAREA RAIL/TOTAREA RAIL/TOTAREA RAIL/TOTAREA
\end{tabular}

Tab. 4 - Variables included in the final model. (SE): Standard error; (df): degrees of freedom; (CI): Confidence Intervals.

\begin{tabular}{|c|c|c|c|c|c|c|c|c|c|c|}
\hline \multirow[b]{2}{*}{ Variable } & \multirow{2}{*}{ 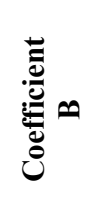 } & \multirow[b]{2}{*}{ 窝 } & \multirow{2}{*}{$\frac{\frac{\pi}{\pi}}{\pi}$} & \multirow[b]{2}{*}{ 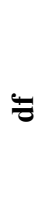 } & \multirow[b]{2}{*}{$\stackrel{0}{0}$} & \multirow{2}{*}{ 気 } & \multicolumn{2}{|c|}{$\begin{array}{l}\text { 95.0\% CI } \\
\operatorname{EXP(B)}\end{array}$} & \multirow{2}{*}{ 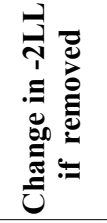 } & \multirow{2}{*}{ 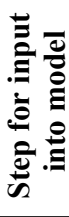 } \\
\hline & & & & & & & لَّ & 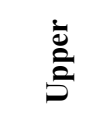 & & \\
\hline $\begin{array}{c}\text { HIKETRAIL/ } \\
\text { TOTAREA }\end{array}$ & 0.479 & 0.109 & 19.345 & 1 & 0.000 & 1.615 & 1.304 & 1.999 & 24.381 & 1 \\
\hline AGRPAST & 0.028 & 0.007 & 18.798 & 1 & 0.000 & 1.029 & 1.016 & 1.042 & 47.875 & 1 \\
\hline FORHOL & 0.008 & 0.003 & 10.006 & 1 & 0.002 & 1.008 & 1.003 & 1.013 & 8.514 & 2 \\
\hline $\begin{array}{r}\text { FORROAD/ } \\
\text { TOTAREA }\end{array}$ & 0.247 & 0.051 & 23.273 & 1 & 0.000 & 1.280 & 1.158 & 1.416 & 36.624 & 1 \\
\hline $\begin{array}{l}\text { RAIL/ } \\
\text { TOTAREA }\end{array}$ & 3.033 & 0.371 & 66.820 & 1 & 0.000 & 20.758 & 10.031 & 42.955 & 79.014 & 1 \\
\hline CONSTANT & -1.249 & 0.121 & 106.243 & 1 & 0.000 & 0.287 & - & - & - & - \\
\hline
\end{tabular}

conducted for all five datasets independently. All variables with a correlation higher than 0.5 were not further considered for the model building procedure. Five different models have been calculated with the re- maining variables using the different datasets in order to choose the best fit to Austrian conditions.

Various methods were tested examining the level of significance through which the variables were introduced and removed from the equation. Variables were introduced into the model according to a significance of $\mathrm{p}<0.05$ (Wald significance) and removed from the model with a $p>0.1$ (Wald significance - see Martinez et al. 2009). The Nagelkerke's $\mathrm{R}^{2}$ test and the likelihood ratio $-2 \mathrm{LL}$ value was used to estimate goodness-of -fit (Menard 2008). 2 × 2 classification tables of observed and predicted responses were calculated in order to test the predictive capability of the models. To this purpose, municipalities were categorized with a probability threshold of 0.5 . Municipalities with values lower than 0.5 were classified as being of low ignition danger and would therefore assigned as "no fire event" (0), whereas municipalities with a value higher than 0.5 would be classified as having a high danger of ignition and be assigned 1 as a predictive value for a recorded "fire event".

In order to be able to evaluate the influence of individual variables in the model, a number of criteria were computed and analyzed:

- the Nagelkerke's $\mathrm{R}^{2}$ and the Log-Likelihood ratio;

- the exponential of the logit coefficient B where $\operatorname{Exp}(\mathrm{B})<1$ corresponds to an increased value of the variable consistent with decreasing odds of a fire occurrence, whereas values of $\operatorname{Exp}(B)>1$ correspond to increasing odds of a fire occurrence;

- the step at which the variable was introduced in the model,

- the change in likelihood in case of the removal of the variable.

Even though other levels and approaches for assessing probability could be used (see Castedo-Dorado et al. 2011) the cut-off point 0.5 - the midpoint of the logistic function - was chosen for this study, since it is the one most extensively used in other comparable studies (Jamnick \& Beckett 1988, Vasconcelos et al. 2001, Martinez et al. 2009).

The outputs of the logistic regression model were compared to the spatial patterns of the original forest fire database. The binary classification of municipalities in high or low danger was compared with the actual values of the original dataset, assessing overand under-estimation using 0.5 as classification criterion. Underestimations would be the municipalities with predicted low ignition danger though actually having a high forest fire danger, while overestimation would be the opposite.

\section{Results}

The best logistic model to analyze the influence of socio-economic factors on forest fire ignition has been selected out of the five models computed (Tab. 2 and Tab. 3) in order to identify the best combination of explaining variables. Railroad density (RAIL/ TOTAREA), density of forest roads (FOR- 
ROAD/TOTAREA) and hiking trail density (HIKETRAIL/TOTAREA) were found to be significant in all five models. Model 2 has been chosen as the best model to represent the influence of socio-economic factors on forest fire ignition. In selecting the final model a combined evaluation of the statistical parameters for significance (Tab. 2), the socio-economic factors in the model (Tab. 3) and the percentage of predicting observed fire ignitions in the validation set was done. The selected model includes five variables $(\mathrm{p}<0.05$, Tab. 4), predicting forest fire ignition with an accuracy of $54.2 \%$ (Tab. 5a) and a quite acceptable goodness-of-fit, with a Nagelkerke's $\mathrm{R}^{2}$ of 0.153 and a -2 Log-Likelihood of 2158.925 (Tab. 2). The variables included in the selected model indicate that touristic infrastructures (i.e., hiking trail density, agricultural and forestry developments, forest road density and railroad density) are the principal socio-economic and infrastructural factors explaining forest fire danger in Austria. The $2 \times 2$ classification table (Tab. 5a) computed for the model building set with 1710 cases of "fire" and "no fire" events reached a total percentage of correctly predicted cases of 63.4. The validation dataset (Tab. 5b) showed a slightly lower total value of $60.5 \%$. Since the original database is relatively small (955 cases) and forest fires are spread over fairly large areas and long time periods, the results can be considered satisfactory. For both data sets reported in Tab. 5 better performances were obtained in identifying municipalities with lower fire danger (72.8\% for the model building dataset and $63.0 \%$ for the validation dataset). Fig. 1 shows the probabilities distribution of the logistic model for the "fire" and "no fire" events from the model data set (Fig. 1a) and the validation data set (Fig. 1b). In the model data set, a left-sided distribution was obtained, whereas in the validation data set no clear tendency was observed.

A sensitivity analysis has been performed in order to identify the influence of the significant variables included in the model. In Tab. 6 the six variables included in the model are ranked by a global score, obtained by adding the ranks of the five evaluation criteria: the lower is the ranking the more important is the variable in the model. The railroad, hiking trail and forest road density were found to be the most relevant factors independently from the chosen variable of significance. The ranking presented only slight variations with the different criteria, similar trends were observed for the criteria (i), (ii), (iii) and (v).

The variables found to be highly relevant for forest fire danger were used to compare the model prediction power in relation to the real fire observations (Tab. 7). In general, model outputs underestimated the number of forest fires with a low density of variables,

Tab. 5 - Classification table for model building dataset and validation dataset. Percentage of correctly classified: $p=0.5$.

\begin{tabular}{lllccc}
\hline \multirow{2}{*}{ Dataset } & & \multirow{2}{*}{ Class } & \multicolumn{2}{c}{ Predicted } & \multirow{2}{*}{ \% Correct } \\
\cline { 4 - 5 } & & & No fire & Fire & \\
\hline (a) Model building data & Observed & No fire & 622 & 233 & 72.7 \\
& & Fire & 392 & 463 & 54.2 \\
\cline { 2 - 5 } & Total percentage & & & & 63.4 \\
\hline (b) Validation dataset & Observed & No fire & 63 & 37 & 63 \\
& & Fire & 42 & 57 & 58 \\
\cline { 2 - 5 } & Total percentage & & & & 60.5 \\
\hline
\end{tabular}

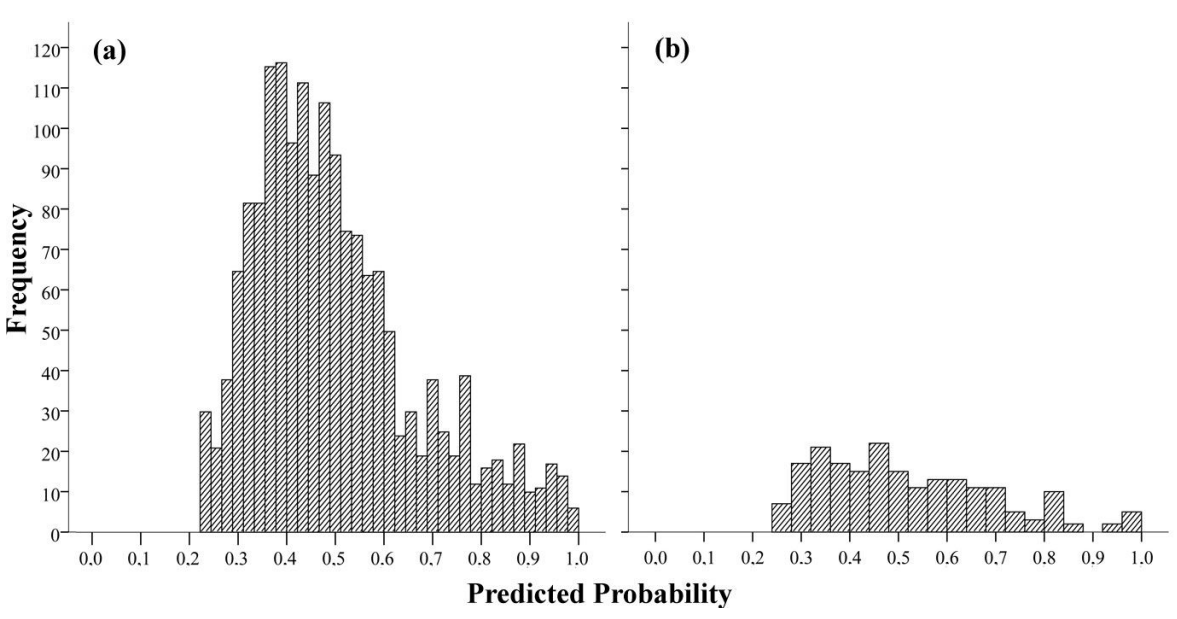

Fig. 1 - Distribution of probabilities of the logistic model for the "fire" and "no fire" events for the validation data set.

Tab. 6 - Ranking of influence for the input variables according to the sensitivity analysis.

\begin{tabular}{lcccccc}
\hline Variables & $\begin{array}{c}\text { Wald } \\
\text { (i) }\end{array}$ & $\begin{array}{c}\text { Exp(B) } \\
\text { (ii) }\end{array}$ & $\begin{array}{c}\text { Step } \\
\text { (iii) }\end{array}$ & $\begin{array}{c}\text { Change in } \\
\text {-2LL (iv) }\end{array}$ & $\begin{array}{c}\text { Regression } \\
\text { Coefficient } \\
\text { B (v) }\end{array}$ & $\begin{array}{c}\text { Global } \\
\text { Score } \\
\text { (Sum) }\end{array}$ \\
\hline RAIL/TOTAREA & 1 & 1 & 1 & 5 & 1 & 8 \\
HIKETRAIL/TOTAREA & 3 & 2 & 1 & 2 & 2 & 9 \\
FORROAD/TOTAREA & 2 & 3 & 1 & 3 & 3 & 11 \\
AGRPAST & 4 & 4 & 1 & 4 & 4 & 16 \\
\hline
\end{tabular}

Tab. 7 - Evaluation of the fire danger map classification with the validation dataset.

\begin{tabular}{lccc}
\hline Fire danger classes & $\begin{array}{c}\text { Forest area } \\
(\mathbf{\%})\end{array}$ & $\begin{array}{c}\text { Ignitions observed } \\
(\mathbf{\%})\end{array}$ & $\begin{array}{c}\text { Average density } \\
\left(\mathbf{f i r e s} / \mathbf{1 0 0} \mathbf{~ k m}^{\mathbf{2}}\right)\end{array}$ \\
\hline Very low $(0-0.19)$ & 24.6 & 9 & 1.16 \\
Low $(0.2-0.50)$ & 31.6 & 12 & 1.2 \\
Medium $(0.51-0.65)$ & 27.6 & 13.5 & 1.54 \\
High $(0.66-0.87)$ & 13.2 & 12 & 2.85 \\
Very high $(0.88-1.0)$ & 3 & 3.5 & 3.71 \\
\hline
\end{tabular}

whereas the number of likely fire ignitions was overestimated by the model for all variables at high densities, respectively. Fig. 2 shows the comparison between the numbers of fire ignitions based on the model prediction in relation to the real fire observations for the railroad density (RAIL/TOTAL) in the respective categories. At very low railroad densities $\left(0.001-0.1 \mathrm{~km} / \mathrm{km}^{2}\right)$ the mo- del has an underestimation for the fire occurrence of $48.3 \%$ and at higher railroad densities $\left(>0.2 \mathrm{~km} / \mathrm{km}^{2}\right)$ an overestimation of more than $25 \%$. Fig. 3 indicates that the model underestimates fire ignitions for municipalities with the category "no forest roads" (FORROAD/TOTAREA) quite high $(54.5 \%)$, whereas the predicted fire ignitions for municipalities with a higher density of 


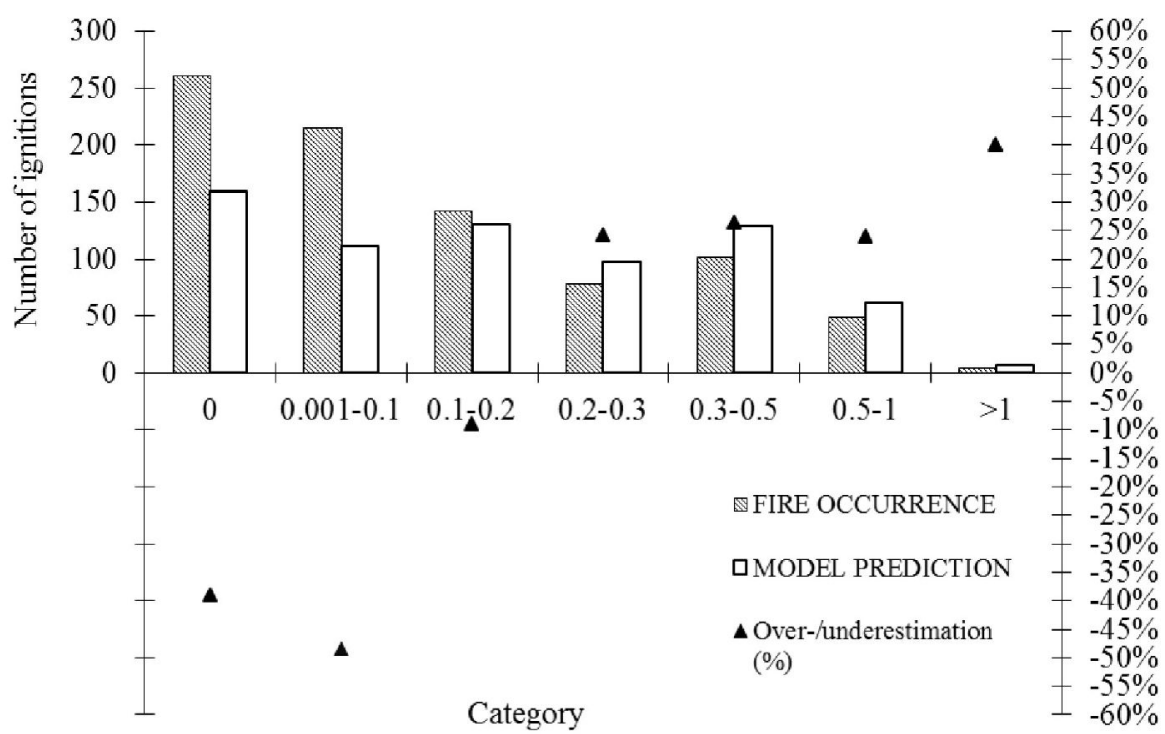

Fig. 2 - Fire ignition in relation to railroad density for original and model dataset (RAIL/TOTAREA).

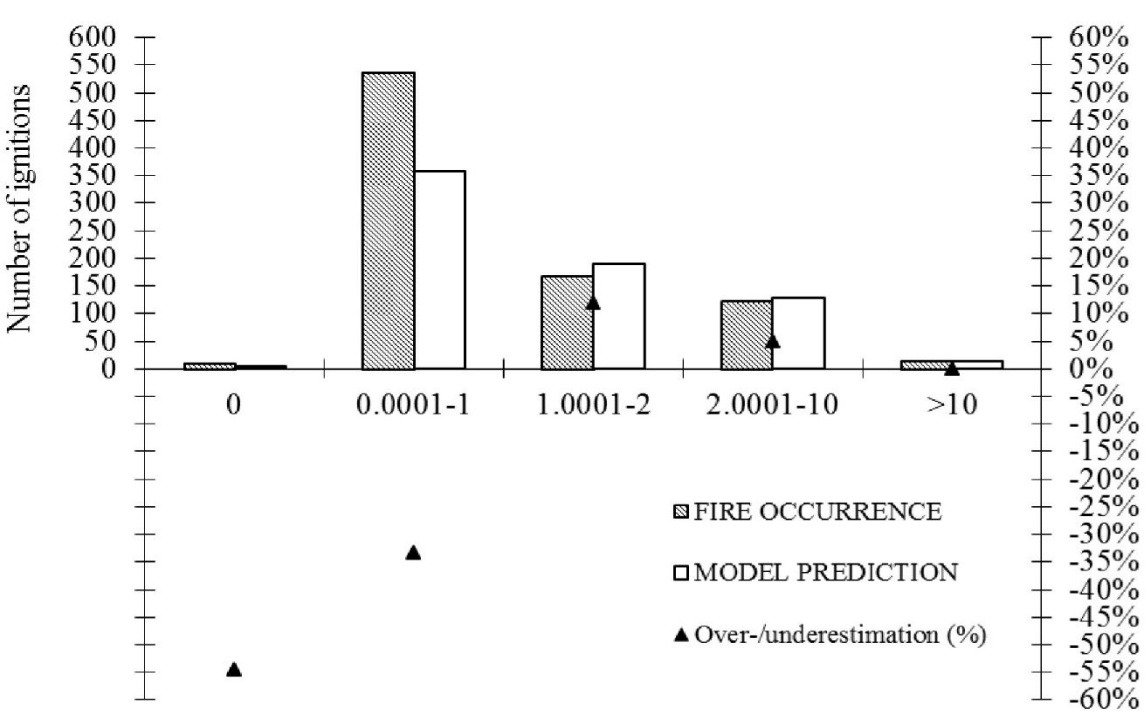

Fig. 3 - Fire ignitions in relation to forest road density for original and model dataset (FORROAD/TOTAREA).

Category

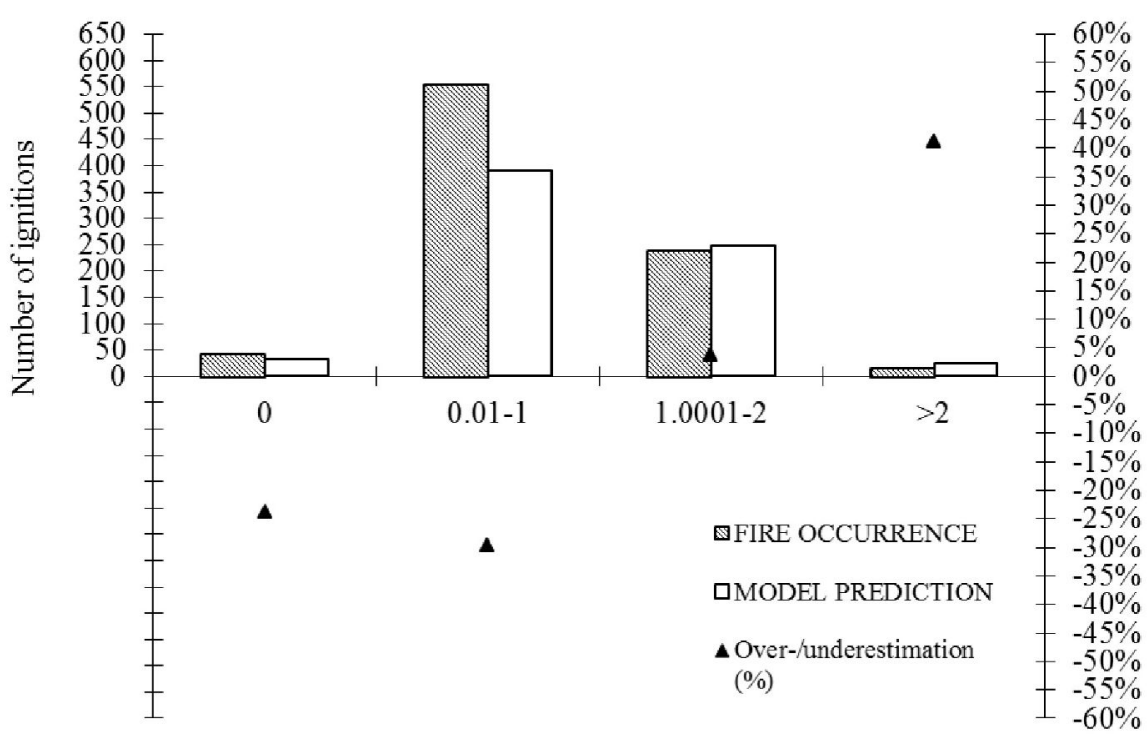

Fig. 4 - Fire ignitions in relation to for hiking trail density (HIKETRAIL/AREA) for original and model dataset.

Category 


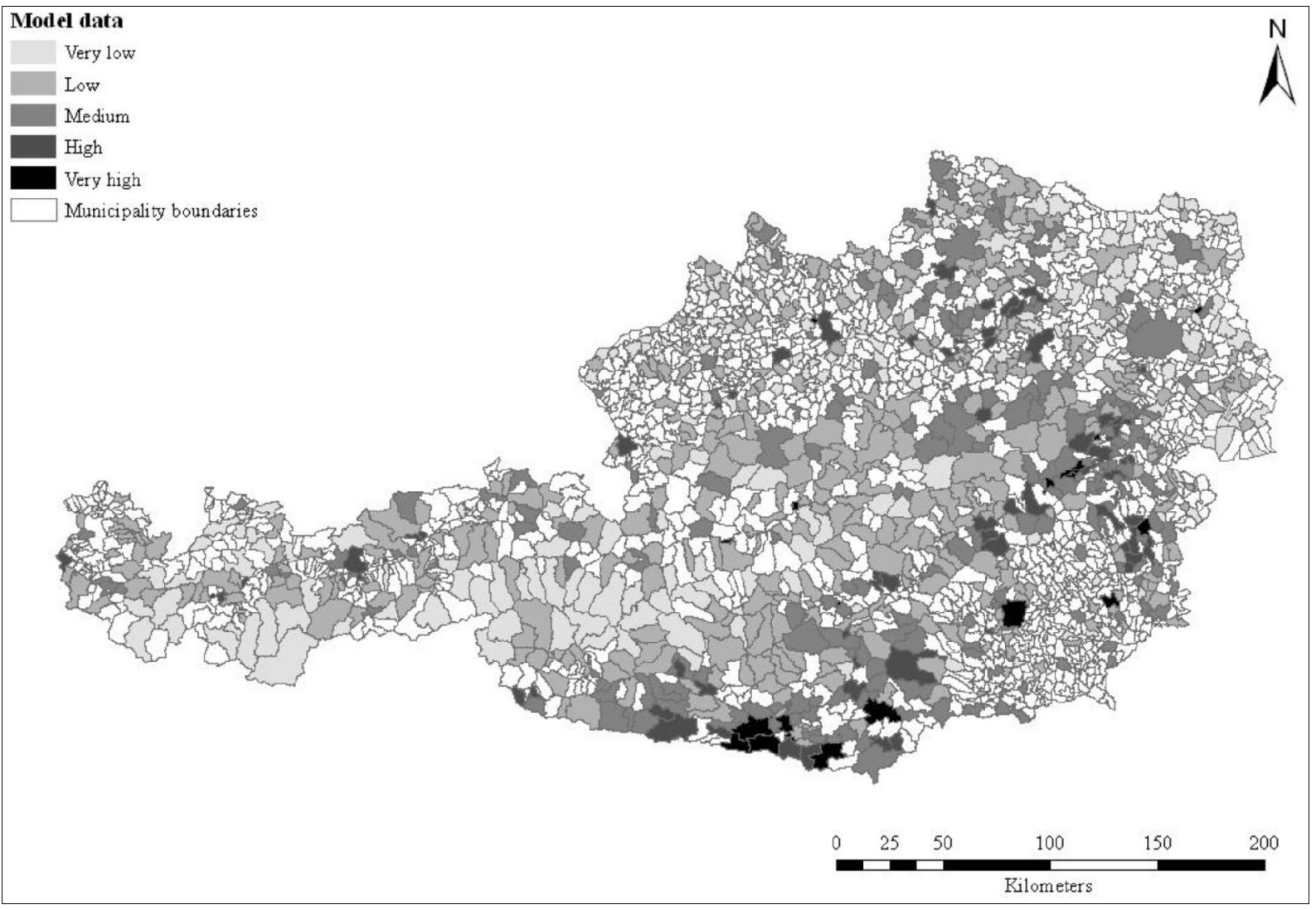

Fig. 5 - Model output on municipality level.

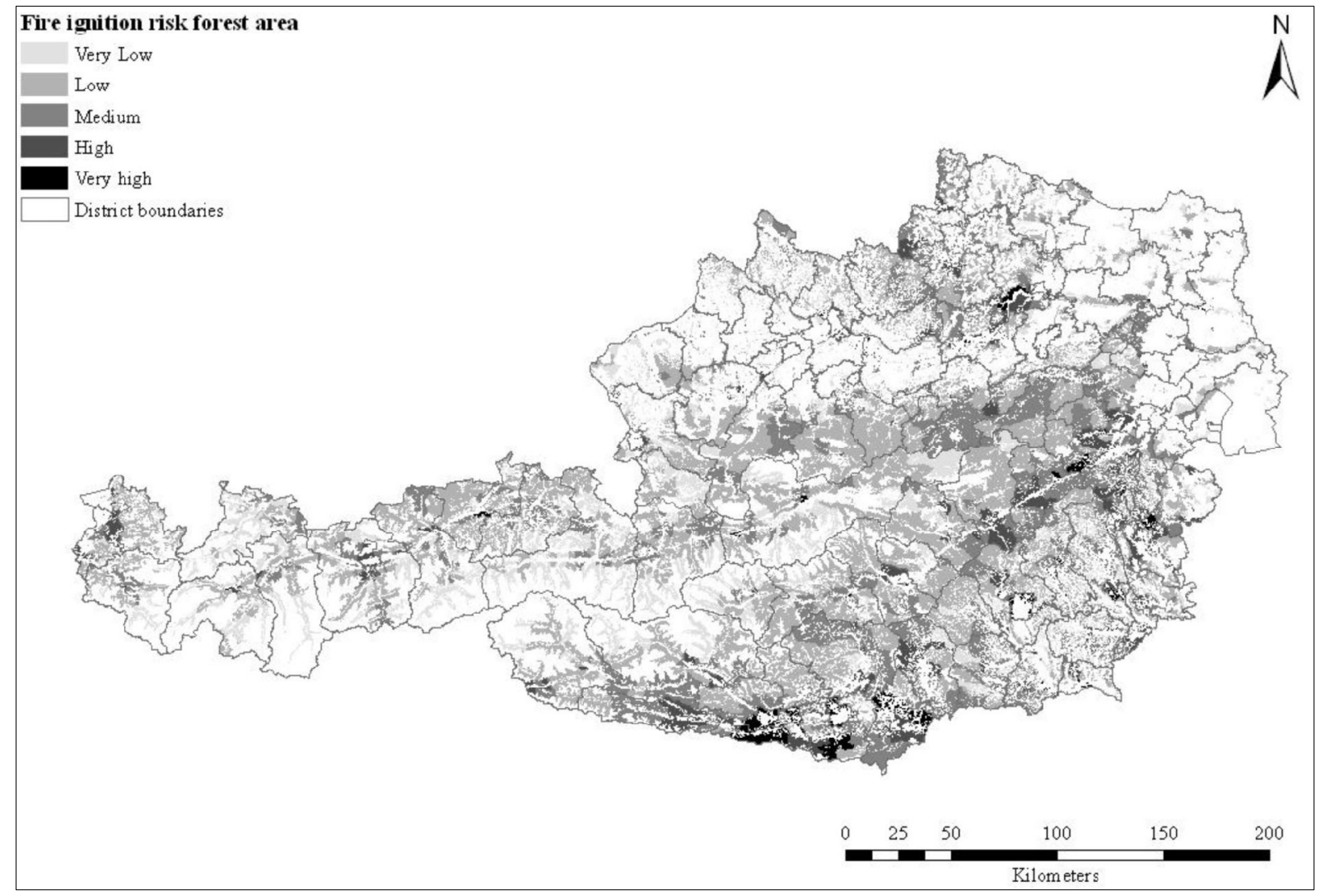

Fig. 6 - Fire ignition risk map for the forest area of Austria on district level. 
forest roads $\left(>1 \mathrm{~km} / \mathrm{km}^{2}\right)$ was comparable to the observed number of forest fires. As regards to the comparison of predicted $v s$. observed fire ignitions for the hiking trail densities (HIKETRAIL/TOTAREA), it becomes evident that the model underestimates the fire occurrence at low hiking trail densities and shows reasonable results for higher densities $\left(>1 \mathrm{~km} / \mathrm{km}^{2}\right)$. Only at high densities $\left(>2 \mathrm{~km} / \mathrm{km}^{2}\right)$ the model overestimates fire ignitions $(>40 \%)$, though the number of records is small in this category (Fig. 4).

All tested models confirm the high significance of socio-economic variables related to infrastructure for forest fire ignition in Austria. In partucilar, the variables railroad density (RAIL/TOTAREA), density of forest roads (FORROAD/TOTAREA) and hiking trail density (HIKETRAIL/TOTAREA) were found to be significant in all models.

Two maps have been generated with the selected model with the aim of illustrating model predictions for all municipalities which data were included in this analysis. Fig. 5 displays the spatial distribution of the forest fire danger at the level of municipalities, and Fig. 6 reports the model prediction for the forest areas only. The estimated probabilities have been classified in five fire danger classes. In Tab. 5 it can be observed that the majority of the forest areas is classified in the very low to medium fire danger classes $(83.8 \%)$; only $16.2 \%$ of the forest area comprises a high to very high forest fire danger. Some $15.5 \%$ of all fire ignitions observed are located in the very high and high danger classes, and the very low and low danger class comprises $21 \%$ of all ignitions observed. The average ignition density per $100 \mathrm{~km}^{2}$ of forest area is in the high fire danger class 2.85 and for the very high fire danger 3.71 , respectively.

\section{Discussion}

The logistic regression carried out in this study provides a model based on a set of socio-economic factors potentially affecting forest fire ignition, in addition to the driving factors of climate and fuel. The logistic model obtained correctly classified $63.1 \%$ of the calibration and $59.5 \%$ of the validation dataset by using the midpoint (0.5) of the logistic function, which is customarily used in most analyses (Martinez et al. 2009). Depending on the fire management strategies and objectives, a different level of probability could be used to estimate forest fire danger. Comparing the medium to high fire danger areas of the model output with the known fire "hot spot" areas in Austria from a previous study (districts of Neunkirchen in Lower Austria, in Kapfenberg in Styria as well as the region around Villach and Arnoldstein/Spittal in Carinthia - Vacik et al. 2011), we found that the midpoint of the Pearson correlation represents the actual fire danger problem in Austria quite well. The average density of the observed fire ignitions of the validation data $\left(3.7\right.$ fires $\left./ 100 \mathrm{~km}^{2}\right)$ in the highest fire danger class is higher than the overall Austrian average.

The dominance of infrastructural variables implies that an easier access to forest areas through infrastructures may lead to an increased fire ignition risk in the future. The influence of agriculture, forestry and tourism on fire ignition seems to be enhanced by the easier accessibility of areas through infrastructure.

The railroad density per total area of a municipality (RAIL/TOTAREA) is related to development processes and its accessibility. Railways have often been related to accidental or negligence fires due to braking trains, broken brake shoes as well as repair works along railway tracks (Johnson et al. 1990, Cardille et al. 2001, Arndt 2007, Martinez et al. 2009). On one hand, Cardille et al. (2001) assume that railroad density is influencing the ignition potential and frequency. On the other hand, the authors argue that railroad density together with road density would strongly affect the probability of a fire being reported in an area by increasing both residents and visitors.

The density of hiking trails per total area of municipality (HIKETREAIL/TOTAREA) indicates easy accessibility of forest areas both for tourists and local inhabitants. According to Romero-Calcerrada et al. (2010) walking around recreational or camping areas is related to an increased susceptibility of forest areas to fire: the short the walking distance around a densely populated area the higher the likelihood of fire for a relatively small area. According to other studies (Vega-Garcia et al. 1995, Cardille et al. 2001), negligence and other destructive activities such as arson may well be connected to this variable.

The density of forest roads per municipality (FORROAD/TOTAREA) is linked to the accessibility to forestry machinery and to enhanced human activity in forests such as timber harvesting and slash burning. Uhl \& Buschbacher (1985) and Fredericksen \& Putz (2003) identified these activities as potential causes for fire ignition and associated them with an increased susceptibility of forests to fire. Also Gossow \& Frank (2003) argue that salvage harvesting carried out when wind blows can lead to subsequent burns as a consequence of inappropriate engineering techniques. Another problem in this context is the simultaneous use of forest roads for timber harvest and tourist activities (such as hiking or mountain biking), which leads to a higher ignition probability.

In this study variables connected to infrastructure - especially railroads, hiking trails and forest roads - seem to be of great significance for forest fire ignition in Austria. Contrary to other studies such as Vega-Gar- cia et al. (1995), Cardille et al. (2001) or Sebastián-López et al. (2008) road density was the only infrastructural predictor not significant in the model.

Unlike other regions such as Mediterranean countries, agricultural variables were not found to play a major role for ignition of forest fires in Austria (see Vega-Garcia et al. 1995, Cardille et al. 2001, Goldammer 2003, Sebastián-López et al. 2008, Martinez et al. 2009). In this study, factors such as agricultural machinery or the high partitioning of agricultural properties (which are considered to be relevant for wildfire ignition by other studies as a consequence of agricultural burnings - Martinez et al. 2009) were not found to be of significance for Austria. Similarly, customary burning related to the persistence of livestock under traditional management was not found to be of relevance for Austrian conditions. These practices are legally banned in general; only a pilot program in Carinthia tries to improve the grazing capacity and quality for domestic livestock by alpine burning practices (Kerschbaumer et al. 2007). However, these practices seem to be only of local relevance and cannot be generalized for Austrian conditions. Additionally, factors related to fire prevention activities, socioeconomic changes, land use abandonment or an increasing urbanization, land use disputes or unemployment rates (Goldammer 2003, Leone et al. 2003, Brosofske et al. 2007, Sebastián-López et al. 2008, Martinez et al. 2009) do not seem to have relevance for forest fire ignition in Austria. Nonetheless, it is worth noticing that only forest fire ignitions have been considered in this study, while fire ignitions on agricultural land have been excluded.

As tourism is still one of the most important income sources in Austria (Statistik Austria 2010) the increasing number of visits and outdoor activities might lead to an increased ignition on a regional level in the future. Although studies such as Guyette \& Dey (2000), Cardille et al. (2001) or Guyette $\&$ Spetich (2003) have found a clear connection between factors related to population density and fire danger, these factors were not found to be relevant in the Austrian context. Other international studies confirm that population density play only a minor role as for forest fires (Brosofske et al. 2007). Variables related to population density were not significantly related to fire danger in this study. We assume that the probability for fire ignition is underestimated in areas with a low density of variables relevant for fire ignition. In this context the studies of Zumbrunnen et al. (2011) have emphasized the non-linear nature of the relationships between fire occurrence and anthropogenic drivers. As road density was no longer correlated with fire occurrence above a certain threshold in two cantons of Switzerland, the 
authors concluded that expected future increase and spatial concentration of the human population may not result in a further increase in fire risk.

Contrary to the findings of other studies (Catry et al. 2009, Martinez et al. 2009), a high number of forest fires is predicted for areas with a low density of variables significant for fire ignition. Although a high average density of forest fire ignitions per fores area occurs in the highest fire danger class, the probability of fire occurrence was found to be higher in districts further away from areas densely populated or with a high density of infrastructure. According to Brosofske et al. (2007) the explanation might be that arsonists seek especially remote areas to avoid capture. Moreover, the authors argue that the detection of forest fires might be lower in remote areas due to a lower density of infrastructure and therefore a generally low level of human activity in forests. These hypotheses might partly hold for the mountain forests in Austria. In general, a high level of fire detection is assumed as the average size of burned areas of most fires in the database is small. This assumption is supported by findings of Cardille et al. (2001) who found that the low number of forest fire ignitions in areas with a high density of infrastructure and population strongly enhance the probability of a fire being reported.

\section{Conclusions}

In this study the logistic regression technique has been chosen to model forest fire ignition using relevant socio-economic factors as predictors. No meteorological parameters, topographic elements or fuel conditions were included since most of these factors require a fine-scale analysis, such as the province level. Our results prove that socio-economic variables found to be significant in other areas more prone to fire ignition risk (Catry et al. 2009, Martinez et al 2009) have little relevance under the extant conditions in Austria, since many of these factors either do not exist or have minor impact for forest fire ignition risk.

The construction of the model was based on a logistic regression analysis. This method is more advisable than multiple regression, where the assumption of normality is often not met. We tested different logistic models to analyze and compare relevant socio-economic factors and to identify potential trends within the variables. Variable selection in the colinearity-exclusions process is always subjective and sometimes leading to different results. However, we found that the selected variables underlying the five models reflected the Austrian conditions fairly reasonable.

The results obtained in this investigation may be improved through the application of techniques less sensitive to correlations and nonlinear relationships among independent variables as well as the non-parametric distribution showed by most of the independent variables (Fotheringham et al. 2002, Martinez et al. 2009). Performances of the model could be further improved by carrying out spatially explicit models such as the geographically weighted regression (Fotheringham et al. 2002). First attempts using Geographic Weighted Regression have provided interesting results in the European Mediterranean (Koutsias et al. 2005, 2010). The logistic probabilities would allow human factors to be integrated with meteorological factors (Arpaci et al. 2013) and fuel conditions. Statistical or physical models could be used for integration of factors in order to build an integrated fire danger model (Martinez et al. 2009).

So far, records on wildfires and forest fires have not been documented consistently by the respective agencies, municipalities and fire brigades in Austria. The dataset underlying this study has been established in the last four years and the process of data assembly is still ongoing. Similar to other studies, the dataset still contains uncertainties regarding the size and location of forest fires and it is still incomplete because of the decentralized documentation of fire records (Vacik et al. 2011, Eastaugh \& Vacik 2012). For the above reasons and the overall small dataset available, in this study we did not consider the causes underlying forest fire ignition in Austria. Therefore, the analysis carried out can be seen as the first step of this research.

\section{Acknowledgments}

This research has been partly conducted within the frame of the Austrian Forest Research Initiative (AFFRI), which is funded by the Austrian Science Funds (FWF) - reference number L539-N14, and within the European Project ALP FFIRS (Alpine Forest Fire Warning System), which is funded by the European Regional Development fund of the Alpine Space Program - reference number 15-2-3-IT.

\section{References}

AFI (2011). Austrian Forest Inventory. Österreichische Waldinventur 2007/2009, BFW-Praxisinformation Nr. 24. Bundesforschungsanstalt und Ausbildungszentrum für Wald, Naturgefahren und Landschaft.

Amatulli G, Pérez-Cabello F, de la Riva J (2007). Mapping lightning/human-caused wildfire occurrence under ignition point location uncertainty. Ecological Modelling 200: 321-333. - doi: 10.1016/j.ecolmodel.2006.08.001

Andrews PL, Loftsgaarden DO, Bradshaw LS (2003). Evaluation of fire danger rating indexes using logistic regression and percentile analysis. International Journal of Wildland Fire 12: 213226. - doi: 10.1071/WF02059

Arndt N (2007). Problem of fires on embankments along railway routes in Austria. Masterarbeit, Univ. für Bodenkultur, Vienna, Austria. [online] URL: https://zidapps.boku.ac.at/abstracts/oe list.php?paID $=3 \&$ paCF $=0 \&$ paLIST $=0 \& p a S I D=$ 5934

Arpaci A, Eastaugh CS, Vacik H (2013). Selecting the best performing fire weather indices for Austrian ecoregions. Theoretical and Applied Climatology. - doi: 10.1007/s00704-013-0839-7 Bellgardt E (1997). Statistik mit SPSS: ausgewählte Verfahren für Wirtschaftswissenschaftler. München, Vahlen X, pp. 277. ISBN 3-8006-2197-5 [in German]

Beniston M, Diaz HF, Bradley RS (1997). Climatic change at high elevation sites: an overview. Climatic Change 36: 233-251. - doi: 10.1007/ 978-94-015-8905-5 1

Brauchle T (2006). Tourismus im Alpenraum, Chancen und Risiken eines bedeutenden Schweizer Wirtschaftssektors im Umbruch. Informationsheft Forum Raumentwicklung no. 34, Schweizerische Eidgenossenschaft, Bundesamt für Raumentwicklung, Bern, Swiss. Abdruck erwünscht mit Quellenangabe, Belegexemplar an ARE. ISSN 1660-624 8. [in German]

Brosofske KD, Cleland DT, Saunders SC (2007). Factors influencing modern wildfire occurrence in the Mark Twain National Forest, Missouri. Southern Journal of Applied Forestry 31 (2): 7384.

Brown TJ, Hall BL, Westerling AL (2004). The impact of twenty-first century climate change on wildland fire danger in the Western United States, an application perspective. Climatic Change 62: 365-388. - doi: 10.1023/B:CLIM. 0000013680.07783.de

Cardille JA, Ventura SJ, Turner MG (2001). Environmental and social factors influencing wildfires in the Upper Midwest, USA. Ecological Applications 11 (1): 111-127. - doi: 10.1890/ 1051-0761(2001)011[0111:EASFIW]2.0.CO;2 Castedo-Dorado F, Rodriguez-Perez JR, MarcosMenendez JL, Alvarez-Taboadam MF (2011). Modelling the probability of lightning-induced forest fire occurrence in the province of León (NW Spain). Forest Systems 20 (1): 95-107. doi: 10.5424/fs/2011201-9409

Catry FX, Rego FC, Bação F, Moreira F (2009). Modelling and mapping wildfire ignition risk in Portugal. International Journal of Wildland Fire 18: 921-931. - doi: 10.1071/WF07123

Chuvieco E, Congalton RG (1989). Application of remote sensing and geographical information system to forest fire hazard mapping. Remote Sensing of the Environment 29: 147-159. - doi: 10.1016/0034-4257(89)90023-0

Chuvieco E, Salas, FJ, Carvacho L, RodriguezSilva F (1999). Integrated fire risk mapping. In: "Remote Sensing of Large Wildfires in the European Mediterranean" (Chuvieco E ed). Springer-Verlag, Berlin, pp. 61-84.

Chuvieco E, Allgöwer B, Salas FJ (2003). Integration of physical and human factors in fire danger assessment. In: "Wildland Fire Danger Estimation and Mapping - the Role of Remote Sensing Data" (Chuvieco E ed). World Scientific Pub- 
lishing, Singapore, pp. 197-218.

Chuvieco E, Aguado I, Yebra M, Nieto H, Salas J, Martín MP, Vilar L, Martínez J, Martín S, Ibarra $\mathrm{P}$, de la Riva J, Baeza J, Rodríguez F, Molina J R, Herrera MA, Zamora R (2009). Development of a framework for fire risk assessment using remote sensing and geographic information system technologies. Ecological Modelling 221: 46-58. doi: 10.1016/j.ecolmodel.2008.11.017

Conedera M, Torriani D, Neff C, Ricotta C, Bajocco S, Pezzatti GB (2011). Using Monte Carlo simulations to estimate relative fire ignition danger in a low-to-medium fire-prone region Forest Ecology and Management 261: 21792187. - doi: 10.1016/j.foreco.2010.08.013

Donoghue LR, Main WA (1985). Some factors influencing wildfire occurrence and measurement of fire-prevention effectiveness. Journal of Environmental Management 20: 87-96.

Dumas E, Jappiot M, Tatoni T (2008). Mediterranean urban-forest interface classification (MUFIC): a quantitative method combining SPOT5 imagery and landscape ecology indices. Landscape and Urban Planning 84: 183-190. doi: 10.1016/j.landurbplan.2007.12.002

Eastaugh CS, Vacik H (2012). Fire size/frequency modelling as a means of assessing wildfire database reliability. Austrian Journal of Forest Science 129 (3-4): 228-247. [online] URL: http://www.forestscience.at/fileadmin/user_upload/CB1203-4 T4 Abstr.pdf

Environmental Agency Austria (2012). Corine Landcover. [online] URL: http://www.umweltbundesamt.at/umwelt/raumordnung/flaechennut zung/corine

Fotheringham AS, Brunsdon $\mathrm{C}$, Charlton $\mathrm{M}$ (2002). Geographically weighted regression. The analysis of spatially varying relationships. John Wiley and Sons, West Sussex, UK, pp. 269.

Fredericksen TS, Putz FE (2003). Silvicultural intensification for tropical forest conservation. Biodiversity and Conservation 12: 1445-1453. doi: 10.1023/A:1023673625940

Fried JS, Torn MS, Mills E (2004). The impact of climatic change on wildfire severity: a regional forecast for northern California. Climatic Change 64: 169-191. - doi: 10.1023/B:CLIM 0000024667.89579.ed

Gambino R, Romano B (2003). Territorial strategies and environmental continuity in mountain regions: the case of the Apennines. In: Proceedings of the "World Heritage Mountain Protected Area Field Workshop. Linking protected areas along the mountain range" (Hamilton L, Sandwith T, Rushworth I, Krueger S, Potter D, Zunckle K, Worboys G, Harmon D eds). Durban (South Africa) 5-8 September 2003. The Nature Conservacy, Italian Ministry of Environment, Rome, Italy, University of Turin, Italy, University of L'Aquila, Italy, pp. 16. [online] URL: http://dau.ing.univaq.it/planeco/staff/romano/pdf pubblicazioni/DURBAN_2003.pdf

Gehrig-Fasel J, Guisan A, Zimmermann NE (2007). Tree line shifts in the Swiss Alps: climate change or land abandonment? Journal of Vegetation Science (18): 571-582. - doi: 10.1111 /j.1654-1103.2007.tb02571.x

Goldammer JG (2003). Towards international cooperation in managing forest fire disasters in the Mediterranean region. International Forest Fire News 27: 81-89. - doi: 10.1007/978-3-642-558 54-2 54

Gossow H, Frank G (2003). Waldbrand auf Windwurf - eine unheilige Allianz. Oesterr. Forstz. 114 (9): 8-9. [in German]

Grissino-Mayer HD, Romme WH, Floyd ML, Hanna DD (2004). Climatic and human influences on fire regimes of the southern San Juan Mountains, Colorado, USA. Ecology 85 (6): 1708-1724. - doi: 10.1890/02-0425

Guyette RP, Dey DC (2000). Humans, topography and wildland fire: the ingredients for long-term patterns in ecosystems. In: Proceedings of the "Workshop on Fire, People and the Central Hardwood Landscape" (Yaussey DA ed). Gen. Tech. Rep. NE-274, USDA Forest Service, Newton Square, PA, USA, pp. 28-35.

Guyette RP, Spetich MA (2003). Fire history of oak-pine forests in the Lower Boston Mountains, Arkansas, USA. Forest Ecology and Management 180: 463-474. - doi: 10.1016/S0378-1127 (02)00613-8

Hall CM, Page SJ (2009). Progress in tourism management: from the geography of tourism to geographies of tourism - a review. Tourism Management 30 (1): 3-16. - doi: 10.1016/j.tourman. 2008.05.014

Heinrichs AK, Kohler Y, Ullrich A (2010). Implementing a Pan-Alpine ecological network. A compilation of major approaches, tools and activities BfN-Skripten 273. [online] URL: http://www.alpine-ecological-network.org/pdfs/ 894_en/at_download/file

Jamnick MS, Beckett DR (1988). A logit analysis of private woodlot owners harvesting decisions in New Brunswick. Canadian Journal of Forest Research 18: 330 - 336. - doi: 10.1139/x88-050 Johnson EA, Fryer GI, Heathcott MJ (1990). The Influence of man and climate on frequency of fire in the Interior Wet Belt Forest, British Columbia. The Journal of Ecology 78 (2): 403 . doi: $10.2307 / 2261120$

Kalabokidis KD, Konstantinidis P, Vasilakos C (2002). GIS analysis of physical and human impact on wildfire patterns. In: "Forest Fire Research and Wildland Fire Safety" (Viegas ed). Millpress, Rotterdam, The Netherland. [ISBN 90-77017-72-0]

Kerschbaumer N, Huber T, Bergthaler GJ, Derbuch G, Friess T (2007). Fallbeispiele zur Alpinen Brandwirtschaft - Auswirkungen auf Vegetation und Fauna. Studie im Auftrag der Arge Naturschutz, Afritz, Klagenfurt, Austria, pp. 10. [in German]

Koutsias N, Martinez J, Chuvieco E, Allgöwer B (2005). Modelling wildland fire occurrence in southern Europe by geographically weighted regression approach. In: Proceedings of the " 5 th International Workshop on Remote Sensing and GIS Applications to Forest Fire Management: Fire Effects Assessment" (De la Riva J, PérezCabello F, Chuvieco E eds). Zaragoza (Spain)
16-18 June 2005. EARSeL Forest Fire Specal Interest Group, pp. 57-60. [online] URL: http://earsel-ffsig.web.auth.gr/sites/default/files/ Koutsias\%20et\%20al.pdf

Koutsias N, Martínez-Fernández J, Allgöwer B (2010). Do factors causing wildfires vary in space? Evidence from geographically weighted regression. GIScience and Remote Sensing 47 (2): 221. - doi: 10.2747/1548-1603.47.2.221

Leone V, Lovreglio R, Fernandez JM (2002). Forest fires and anthropogenic influences. a study case (Gargano National Park, Italy). In: "Forest Fire Research \& Wildland Fire Safety" (Viegas ed). Millpress, Rotterdam, The Netherlands. ISBN 90-77017-72-0

Leone V, Koutsias N, Martinez J, Vega-Garcia C, Allgöwer B, Lovreglio R (2003). The human factor in fire danger assessment. In: "Wildland Fire Danger Estimation and Mapping. The Role of Remote Sensing Data" (Chuvieco E ed). World Scientific Publishing, Singapore, vol. 4, pp. $143-194$.

Lindner M, Maroschek M, Netherer S, Kremer A, Barbati A, Garcia-Gonzalo J, Seidl R, Delzon S, Corona P, Kolström M, Lexer MJ, Marchetti M (2010). Climate change impacts, adaptive capacity, and vulnerability of European forest ecosystems. Forest Ecology and Management 259: 698709 - doi: 10.1016/j.foreco.2009.09.023

Loftsgaarden D, Andrews PL (1992). Constructing and testing logistic regression models for binary data: applications to the National Fire Danger Rating System. General Technical Report 286, USDA Forest Service, Ogden, UT, USA.

Martell DL, Otukol S, Stocks BJ (1987). A logistic model for predicting daily people-caused fire occurrence in Ontario. Canadian Journal of Forestry Research 17: 394-401 - doi: 10.1139/ x87-068

Martinez J, Vega-Garcia C, Chuvieco E (2009). Human-caused wildfire risk rating for prevention planning in Spain. Journal of Environmental Management 90 (2): 1241-1252 - doi: 10.1016/ j.jenvman.2008.07.005

Menard S (2008). Applied logistic regression analysis $\left(2^{\text {nd }}\right.$ edn). Quantitative applications in the Social Sciences 106, Sage, Thousand Oaks, CA, USA. - ISBN: 978-0-7619-2208-7

Mollicone D, Eva HD, Achard F (2006). Human role in Russian wild fires. Nature 440: 436-437. doi: 10.1038/440436a

Müller M, Vacik H, Diendorfer G, Arpaci A, Formayer H, Gossow H (2013). Analysis of lightning induced forest fires in Austria. Theoretical and Applied Climatology 111 (1-2): 183193. - doi: 10.1007/s00704-012-0653-7

Nordregio (2004). Mountain areas in Europe: analysis of mountain areas in EU Member States, acceding and other European countries. Nordregio Report 1, pp. 271. - ISBN: 91-89332-35-0 Pezzati GB, Bajocco S, Torriani D, Conedera M (2009). Fire regimes in Southern Europe. Selective burning of forest vegetation in Canton Ticino (southern Switzerland). Plant Biosystems 143(3): 609-620. - doi: 10.1080/11263500903233292 
Romero-Calcerrada R, Barrio-Parra F, Millington JDA, Novillo CJ (2010). Spatial modelling of socioeconomic data to understand patterns of human-caused wildfire ignition risk in the SW of Madrid (central Spain). Ecological Modelling 221: 34-45. - doi: 10.1016/j.ecolmodel.2009. 08.008

Schumacher S, Bugmann H (2006). The relative importance of climatic effects, wildfires and management for future forest landscape dynamics in the Swiss Alps. Global Change Biology 12: 1435-1450. - doi: 10.1111/j.1365-2486. 2006.01188.x

Sebastián-López A, Salvador-Civil R, Gonzalo-Jimenéz J, San Miguel-Ayanz J (2008). Integration of socio-economic and environmental variables for modelling long-term fire danger in Southern Europe. European Journal of Forest Research 127: 149-163. - doi: 10.1007/s10342-007-0191-

Statistik Austria (2010). Tourismus in Zahlen Österreich 2009/2010. Web Site. [online]: http:// www.statistik.at

Steininger KW, Weck-Hannemann H (2002). Global environmental change in Alpine regions: Recognition, impact, adaptation and mitigation. Edward Elgar, Cheltenham, UK, pp. 271. ISBN: 1-84376-183-1

Theurillat JP, Guisan A (2001). Potential impact of climate change on vegetation in the European
Alps: a review. Climatic Change 50: 77-109. doi: 10.1023/A:1010632015572

Uhl C, Buschbacher R (1985). A disturbing synergism between cattle ranch burning practices and selective harvesting in the eastern Amazon. Biotropica 17: 265-268. - doi: 10.2307/2388588

Vacik H, Arndt N, Arpaci A, Koch V, Müller M, Gossow H (2011). Characterisation of forest fires in Austria. Austrian Journal of Forest Sciences 128 (1): $1-31$

Vasconcelos MJP, Silva S, Tome M, Alvim M, Cardoso Pereira JM (2001). Spatial prediction of fire ignition probabilities. Comparing Logistic Regression and Neural Networks. Photogrammetric Engineering and Remote Sensing 67 (1): 73-81. [online] URL: http://www.asprs.org/a/ publications/pers/2001journal/january/2001_jan 73-81.pdf

Vasilakos C, Kalanokidis K, Hatzopoulos J, Kallos G, Matsinos Y (2007). Integrating new methods and tools in fire danger rating. International Journal of Wildland Fire 16: 306-316. - doi: 10.1071/WF05091

Vega-Garcia C, Woodard T, Adamowicz WL, Lee B (1995). A logit model for predicting the daily occurrence of human caused forest fires. International Journal of Wildland Fire 5: 101-111. - doi: 10.1071/WF9950101

Vilar L, Woolford DG, Martell DL, Martin MP (2010). A model for predicting human-caused wildfire occurrence in the region of Madrid, Spain. International Journal of Wildland Fire 19: 325-337. - doi: 10.1071/WF09030

Wastl C, Schunk C, Leuchner M, Pezzatti GB, Menzel A (2012). Recent climate change: Longterm trends in meteorological forest fire danger in the Alps. Agricultural and Forest Meteorology 162-163: 1-13. - doi: 10.1016/j.agrformet.2012. 04.001

Weibel P, Reineking B, Bugmann H (2009). Projecting forest fires in mountain forests under climate change. Earth and Environmental Science 6. - doi: 10.1088/1755-1307/6/8/382005

Wotton BM, Martell DL, Logan KA (2003). Climate change and people-caused forest fire occurrence in Ontario. Climate Change 60: 275-295. doi: 10.1023/A:1026075919710

Zhang ZX, Zhang HY, Zhou DW (2010). Using GIS spatial analysis and logistic regression to predict the probabilities of human-caused grassland fires. Journal of Arid Environments 74 (3): 386-393. - doi: 10.1016/j.jaridenv.2009.09.024 Zumbrunnen T, Pezzatti GB, Menéndez P, Bugmann H, Bürgi M, Conedera M (2011). Weather and human impacts on forest fires: 100 years of fire history in two climatic regions of Switzerland. Forest Ecology and Management 261 (12): 2188-2199. - doi: 10.1016/j.foreco.2010.10.009 